\title{
PENGAMBILAN KEPUTUSAN KEPALA SEKOLAH DALAM RANGKA PEMBERDAYAAN TENAGA PENDIDIK DI SEKOLAH POLISI NEGARA JAMBI
}

\author{
Tita Meitia*
}

\begin{abstract}
This research performed at Police National Academy in Jambi on year 2009. This research aims to determine; (1) Decision making that were taken by principal in order to empower educators; (2) The level of rationality in decision making by principal in order to empower educators; and (3) Relation between desicion making by principal in order to empower educators at Police National Academy in Jambi. This research included 30 respondent and using Descriptive Methode. Sampling Methode performed by using Stratified random sampling. Data analyzing technique using Descriptive statistic. Decision making that performed by principal at Police National Academy in Jambi in order to empowering educators had improve their motivation, competency, independence, confidence, and team work. Based on finding research, to improve empowerment for educators can be achieved by determining accurate decision that taken by principal.
\end{abstract}

Keywords: Decision making, empowerment.

\section{PENDAHULUAN}

Sekolah Polisi Negara Jambi sebagai salah satu Lembaga Pendidikan Polri yang diarahkan untuk mewujudkan kesiapan, kemampuan dan kekuatan serta ketersediaan sumber daya manusia Polri yang mahir, terpuji dan patuh hukum guna mengemban tugas memelihara keamanan dan ketertiban masyarakat, menegakkan hukum, memberi perlindungan, pengayom dan pelayan masyarakat. Sebagai penyelenggara pendidikan, Sekolah Polisi Negara Jambi memiliki nilai strategis karena disamping menyiapkan para lulusannya untuk dapat melaksanakan tugas secara profesional juga menyiapkan kaderkader Polri yang memiliki kemampuan dan ketrampilan untuk menghadapi tantangan tugas dimasa datang yang semakin kompleks akibat perkembangan ilmu pengetahuan dan tehnologi yang dampaknya akan sangat berpengaruh kepada kualitas gangguan kamtibmas. Untuk memperoleh output atau lulusan yang diharapkan, Sekolah Polisi Negara Jambi secara berkesinambungan dan berlanjut harus melakukan pembenahan, penyesuaian, dan perubahan terhadap hal-hal yang berkaitan dengan kualitas, utamanya pada kualitas tenaga pendidik. Hal ini penting dalam rangka meningkatkan mutu lulusan.

Pembenahan, penyesuaian, dan perubahan terhadap hal-hal yang berkaitan dengan kualitas hasil didik terkait erat dengan kualitas tenaga pendidik, karena beberapa halhal yang mendasar yang menyangkut keterampilan mengajar yaitu; latar belakang pendidikan tenaga pendidik yang beragam, pengalaman tugas yang beragam, motivasi dalam melaksanakan tugas sebagai tenaga pendidik sangat bervariasi. Tenaga pendidik dan tenaga kependidikan di sekolah Polisi Negara jambi saat ini berjumlah 93 orang yang terdiri dari golongan kepangkatan perwira menengah, perwira pertama, bintara dan pegawai negeri sipil dengan latar belakang pendidikan S1 10, dan SLTA 83, diduga

\footnotetext{
* Tenaga pengajar di Sekolah Polisi Negara Jambi, Jalan Bhayangkara km 18 Jambi.
} 
latar belakang pendidikan ini merupakan salah satu penyebab terjadinya kesenjangan kemampuan dalam melaksanakan proses pembelajaran pada Sekolah Polisi Negara Jambi. Salah satu aspek penting didalam meningkatkan kualitas tenaga pendidik untuk meningkatkan mutu lulusan adalah pemberdayaan tenaga pendidik itu sendiri, maka tindakan pengambilan keputusan kepala sekolah didalam peningkatan keterampilan tenaga pendidik di Sekolah Polisi Negara Jambi mutlak diperlukan.

Berdasarkan uraian di atas maka dapat ditarik kesimpulan bahwa tindakan pengambilan keputusan kepala sekolah merupakan aspek yang sangat penting untuk menentukan tingkat kemampuan dan keterampilan tenaga pendidik dalam rangka meningkatkan mutu hasil keluaran pendidikan. Berkaitan dengan upaya pemberdayaan tenaga pendidik manajemen sekolah diarahkan kepada peningkatan mutu dan pengelolaan sekolah itu sendiri. Sekolah sebagai unit pelaksana teknis membutuhkan pengelolaan yang baik, oleh karena itu kepala sekolah Polisi Negara Jambi harus berfikir strategik dan analitik demi kemajuan-kemajuan sekolah, menentukan visi dan misi, tujuan dan sasaran serta membina kepemimpinan yang baik di sekolah. Latar belakang inilah yang akhirnya menimbulkan tindakan dan upaya pengambilan keputusan untuk optimalisasi yang di harapkan dikerjakan oleh sekolah. Apakah tugas sudah dilaksanakan dengan sebaik-baiknya? Jawaban atas pertanyaan ini diharapkan akan dapat dipakai sebagai peningkatan pemahaman tentang pengambilan keputusan di sekolah. Semua kegiatan pendidikan diharapkan membawa dampak yang signifikan bagi peserta didik. Peningkatan kualitas tenaga pendidik di Sekolah Polisi Negara Jambi juga membawa akibat pada kualitas-kualitas apa yang ingin dikembangkan oleh sekolah melalui keputusan yang kontekstual. Oleh karena itu dalam rangka peningkatan mutu dan kualitas hasil didik di Sekolah Polisi Negara Jambi, maka penelitian ini difokuskan pada tindakan pengambilan keputusan Kepala Sekolah Jambi dalam rangka pemberdayaan tenaga pendidik di Sekolah Polisi Negara Jambi.

Pengambilan keputusan menurut Kreitner \& Kinicki (2008:336) "the rational model proposes that managers use a rational, four-step sequence when making decisions:(1) identifying the problem, (2) generating alternatif, (3) selecting a solution, and (4) implementing and evaluating the solution." Pengambilan keputusan adalah tindakan rasional dan logis dalam menetapkan keputusan melalui ; (1) identifikasi masalah; (2) membuat solusi alternatif; (3) memilih solusi; (4) mengimplementasikan dan mengevaluasi solusi. Kreitner \& Kinicki (2008:336) menganjurkan kepada para manajer untuk berpikir rasional dalam menentukan keputusan.

Sedangkan menurut Northcraft \& Neale (1994:144-146) "decisions are response to problems. Problems may vary in importance from figuring out which job you should accept after graduation to deciding which brand of toothpaste you should buy." Keputusan adalah bentuk respon terhadap masalah. Masalah dapat bervariasi dalam hal kepentingan seperti saat kita memilih pekerjaan apa setelah kita lulus. Dijelaskan oleh Northcraft $\mathcal{E}$ Neale terdapat Lima langkah pengambilan keputusan : Five Steps of Decision Making :1) recognition and definition of the problem, 2) information search, 3) alternatif generation, 4) evaluating and choice, 5) implementation and assessment.

Lebih jauh, Northcraft \& Neale menjelaskan bahwa: (1) memahami dan menjelaskan permsalahan dengan benar adalah hal yang sangat penting dalam membuat keputusan. Karena proses pemahaman ini adalah proses persepsi, maka manajer belum tentu menadapatkan pemahaman yang akurat, yang mana akan menghasilkan keputusan yang salah. Dengan kata lain, para pembuat keputusan sering 
teralihkan perhatiannya terhadap permasalahan utama dan keyakinan akan masalah yang mereka yakini dapat diselesaikan, (2) pencarian informasi : pembuat keputusan harus mengumpulkan informasi mengenai suatu permasalahan dan kemungkinan penyelesaiannya. Pada titik ini, pembuat keputusan harus jelas dalam memahami permasalahan dan telah mengumpulkan informasi yang cukup, (3) pembuatan pilihan alternatif : secara teori, manajer sebaiknya terus-menerus menghasilkan pilihan keputusan hingga kemungkinan untuk pilihan lainnya menjadi sangat kecil. Para manajer lebih sering berhenti menghasilkan pilahan alternatif saat mereka merasa telah menemukan pilihan yang berpotensi baik, (4) ketika sejumlah pilihan alternatif telah ditemukan, pembuat keputusan harus menguji dan memilihnya. Pembuat keputusan dapat membandingkan tiap pilihan dengan pilihan lainnya atau membandingkan pilihan dengan tujuan yang ingin dicapai, (5) pelaksanaan dan pengawasan : saat sebuah pilihan dibuat, pembuat keputusan harus melaksanakan keputusan tersebut. Setelah pelaksanaan keputusan, pembuat keputusan dapat mengawasi hasilnya untuk mengetahui perubahan yang mungkin terjadi. Terlepas dari faktor yang mempengaruhi perubahan tersebut, jika keputusan yang diambil tidak mampu menyelesaikan permasalahan, maka proses pembuatan keputusan dapat dimulai kembali.

Pengambilan keputusan sebagaimana diungkapkan Gibson dan Ivancevich (2006:455), "decision are means to achieve or to solve some problems, the outcome of it's process influence by many forces. Problems that occur infrequently, with a great deal of uncertainty and risk surrounding the outcome, require that the manager utilize the entire process. For a problem that occur frequently the entire process is not necessary. If a policy established to handle such problem, manager don't need to develop and evaluate alternatifs each time a problem of this kind arises".

Keputusan dibuat untuk mencapai tujuan atau menyelesaikan masalah, hasil dari proses ini dipengaruhi oleh berbagai faktor luar. Masalah yang terjadi tidak teratur, dengan ketidakpastian dan resiko yang mengelilingi hasil, membutuhkan manajer yang mampu memanfaatkan keseluruhan proses. Untuk masalah yang sering terjadi, keseluruhan proses tidak diperlukan. Jika sebuah aturan diberlakukan untuk mengatasi masalah tersebut, manajer tidak akan perlu untuk mengembangkan dan mengevaluasi pilihan alternatif tiap saat masalah terjadi.

Proses pengambilan keputusan dijelaskan oleh Gibson dan Ivancevich (2006:459), (1) establishing specific goals and objectives and measuring results, (2) identifying problems, (3) developing alternatifs, (4) evaluating alternatifs, (5) choosing an alternatif, (6) implementing the decision, (7) control and evaluation. (1) menghasilkan tujuan khusus dan mengukur keberhasilannya: Sebuah organisasi membutuhkan tujuan dan sasaran di tiap area dimana kinerja berpengaruh secara efektif. Kesamaan tujuan dan sasaran akan menentukan seperti apa hasil yang ingin dicapai dan mengukur hasil yang telah dicapai, (2) mengidentifikasi masalah: secara umum, permasalahan terbagi menjadi tiga jenis :

permasalahan tak tentu, krisis, permasalahan rutin. Permasalahan rutin dan krisis menampakan dirinya dan harus diperhatikan oleh manajer. Masalah tak tentu umumnya harus ditemukan. Sering terjadi dimana masalah tak tentu terlewat tanpa disadari oleh manajer yang tidak perhatian. Karena sebagian besar masalah rutin dan krisis membituhkan perhatian langsung, manajer akan menghabiskan waktu yang sangat besar untuk mengatasinya dan tidak akan punya cukup waktu untuk mengejar kesempatan yang baru, (3) mengembangkan alternatif : Mengembangkan alternatif pilihan merupakan sebuah proses pencarian dimana faktor internal dan faktor eksternal dari sebuah organisasi akan diselidiki untuk memenuhi kebutuhan informasi yang akan 
dikembangkan menjadi pilihan alternatif. Berlawanan dengan yang dibayangkan banyak orang, terdapat hubungan positif antara jumlah pilihan yang ditemukan dan kecepatan sebuah keputusan yang bisa dicapai. Tidak menghasilkan cukup pilihan alternatif sebenarnya bisa memperbesar biaya baik waktu maupun sumber daya yang merupakan komoditas yang harus dihemat oleh tiap organisasi, (4) mengevaluasi pilihan : saat pilihan telah dikembangkan, mereka harus dievaluasi dan dibandingkan. Dalam tiap situasi pengambilan keputusan, tujuan dari pembuatan keputusan adalah untuk memilih pilihan yang akan menghasilkan hasil yang diinginkan, dan hasil yang tidak diinginkan. Hubungan antara pilihan-hasil digolongkan menjadi tiga kondisi : a) kepastian. Pembuat keputusan mengetahui setiap kemungkinan dan hasil dari tiap kemungkinan tersebut, b) ketidakpastian. Pembuat keputusan tidak mengetahui sama sekali kemungkinan yang ada begitu pula dengan hasil dari tiap kemungkinan tersebut, c) resiko. Pembuat keputusan mempunyai sedikit perkiraan menganai kemungkinan dan hasil dari tiap kemungkinan tersebut, (5) memilih pilihan alternatif: tujuan dari memilih pilihan alternatif adalah untuk menyelesaikan masalah dan mencapai tujuan. Sayangnya, sebagian besar manajer yang menggunakan pilihan alternatif jarang sekali mencapai target yang dituju tanpa menimbulkan efek positif dan negatif. Seringkali terjadi di mana dua target tidak dapat diraih secara bersamaan. Solusi keputusan yang optimal adalah sesuatu yang seringkali mustahil dicapai. Pembuat keputusan tidak akan mungkin mengetahui segala pilihan yang tersedia, konsekuensi dari pilihan tersebut, dan kemungkinan pilihan tersebut terjadi. Sehingga, daripada menghasilkan keputusan yang optimal pembuat keputusan membuat keputusan yang memuaskan, memilih pilihan alternatif yang membutuhkan standar yang dapat diterima (memuaskan), (6) melaksanakan keputusan : tiap keputusan yang yang tidak dilaksanakan merupakan suatu yang hanya sedikit lebih baik dari abstraksi. Dengan kata lain, sebuah keputusan harus dilaksanakan secara efektif untuk mencapai tujuan yang telah ditentukan. Tugas dari seorang manajer tidak hanya memilih solusi yang baik namun juga mengubah solusi tersebut menjadi perilaku dalam organisasi. Ini dilakukan dengan cara mengkomunikasikan secara efektif kepada individu dan kelompok yang sesuai, (7) kontrol dan evaluasi : manajeman yang efektif melibatkan pengukuran hasil secara berkala. Hasil yang aktual dibandingkan dengan target yang direncanakan (tujuan) dan perubahannya harus dicatat jika terjadi penyimpangan. Jika tujuan awal harus mengalami peninjauan ulang, maka keseluruhan proses pembuatan keputusan harus dilaksanakan kembali. Sebuah sistem kontrol terhadap evaluasi dibutuhkan untuk meyakinkan bahwa hasil aktual tersebut konsisten dengan hasil yang rencana yang telah ditentukan saat keputusan dibuat.

Lunberg (1964:24) menjelaskan tentang langkah-langkah perilaku pengambilan keputusan. Suatu pengambilan keputusan secara khusus akan mencakup tahapantahapan sebagai berikut : 1) mengenali, mengidentifikasi, dan membatasi masalah, 2) menganalisis dan mengevaluasi masalah, 3) mengadakan kriteria atau standar-standar yang dengannya pemecahan akan evaluasi dinilai dapat diterima dan memadai bagi kebutuhan, 4) mengumpulkan data, 5) merumuskan dan memilih preferensi pemecahan-pemecahan. Menguji rumusan dan pilihan itu sebelumnya dan 6) menerapkan pemecahan yang lebih disukai. Menurut Kreitner and Kinicki (2008:254), "a team of researchers developed a model decision making styles that is based on the idea that styles vary along two different dimensions : value orientation and tolerance for ambiguity." Gaya pengambilan keputusan menggambarkan kombinasi dari bagaimana tiap individu menerima dan merespon rangsangan dan etika umum yang dipilih untuk 
bereaksi terhadap informasi tersebut. Sebuah tim riset mengembangkan model gaya pengambilan keputusan berdasarkan ide bahwa terdapat dua orientasi gaya pengambilan keputusan, yaitu orientasi nilai dan toleransi. Dengan demikian, maka dapat disintesiskan bahwa pengambilan keputusan adalah tindakan dalam menetapkan suatu pilihan, yang dapat dilakukan oleh seseorang maupun bersamasama dengan gaya dan model yang berbeda-beda.

\section{Pemberdayaan}

Pemberdayaan menurut Kreitner and Kinicki (2008:442) adalah, "empowerment is of intrinsic value; it also has instrumental value. Empowerment is relevant at the individual and collective level, and can be economic, social, or political." Selain itu pemberdayaan diartikan juga sebagai nilai yang tidak terlihat secara kasat, dapat memiliki nilai yang instrumental. Pemberdayaan adalah relevant pada level individu dan keseluruhan, dapat dalam ruang lingkup ekonomi, sosial, dan politik. Dalam definisi praktis ; pemberdayaan berhubungan dengan sumber daya, kemampuan, waktu dan dukungan untuk menjadi seorang pemimpin yang memiliki inisiatif. Sebagaimana diungkapkan Steve Kerr (2008:333) "a pioneer in employee empowerment, explaint: "We say empowerment is a moving desicion making down to the lowest level where a competent desicion can be made." Pemberdayaan adalah pengambilan keputusan yang bergerak ke bawah sampai tingkat di mana keputusan yang baik dapat dibuat. Tentu saja hal ini naif dan tidak bijaksana untuk melepaskan wewenang dan tanggung jawab kepada pekerja yang tidak siap dan tidak mampu. Sedangkan menurut Randolph dan Blancahard (2002:80-82) pemberdayaan berarti memberikan kesempatan bagi orang-orang untuk menggunakan akal mereka ketika bekerja dan menggunakan pengetahuan, pengalaman dan motivasi. Pemberdayaan berarti pula sebuah proses melepaskan kekuatan yang ada pada diri setiap orang: pengetahuan, pengalaman dan motivasi serta mengarahkan kekuatan tersebut untuk mencapai hasil positif bagi perusahaan. Menciptakan sebuah kultur pemberdayaan membutuhkan beberapa langkah dan agar pemberdayaan berhasil, para pemimpin harus mengambil sebuah lompatan besar dan melawan kebiasaan dan tradisi. Beberapa peneliti telah menemukan bahwa ketika orang-orang diberdayakan, secara keseluruhan perusahaan mereka mencapai kemajuan, bukti-bukti menunjukkan hubungan positif antara pemberdayaan dan kinerja sehingga akademisi Thomas Malone meyakini kalau pemberdayaan adalah elemen penting bagi perusahaan yang ingin sukses di dalam sistem berbasis pengetahuan.

Konsep dari pemberdayaan membutuhkan penyetaraan dalam pemikiran. Pertama, kekuatan bukanlah kondisi di mana yang satu mendapatkan sedangkan yang lain kehilangan, kekuatan sosial bukan sesuatu yang tidak terbatas sehingga dibutuhkan "win-win thinking". Manajer yang otoriter akan melihat pemberdayaan pekerja sebagai ancaman akan kehilangan nilai penting karena hanya memikirkan untung dan rugi. Penyetaraan kedua melibatkan pemberdayaan sebagai urusan derajat kekuasaan tidak sebagai dasar pegangan.

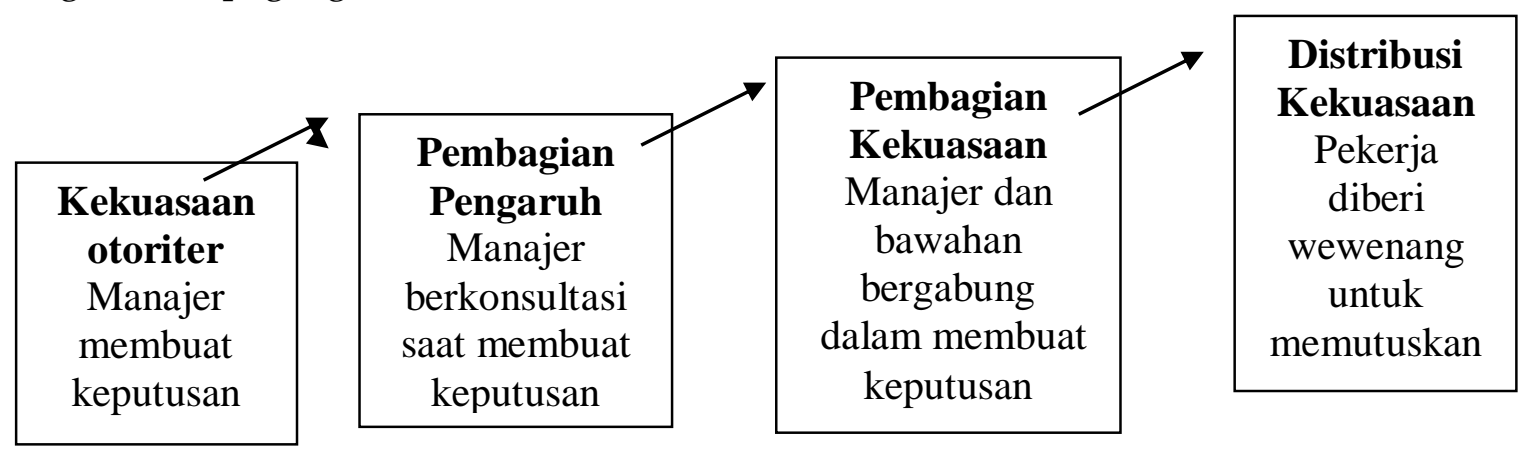




\section{Gambar 1. The evolution of Power: From Domination to Delagation (Robert Kreitner and Angelo Kinicki:2008:334)}

Gambar di atas menggambarkan bagaimana kekuasaan dapat berpindah kepada bawahan secara bertahap. Tujuan utamanya adalah untuk meningkatkan produktivitas dan persaingan dalam pembelajaran organisasi. Tiap langkah dalam perubahan meningkatkan kekuasaan dari kontributor organisasi yang secara tradisi memberi tahu apa, kapan, dan bagaimana mengerjakan sesuatu. Dengan demikian, maka dapat disintesiskan bahwa pemberdayaan adalah proses yang memungkinkan seseorang untuk memperoleh kekuatan, kekuasaan dan pengaruh terhadap orang lain, pemberdayaan dapat juga diartikan sebagai totalitas dari kemampuan seseorang memiliki keputusan dan kekuatan sendiri, memiliki akses ke informasi dan sumber daya untuk mengambil keputusan yang tepat, memiliki berbagai pilihan dan dapat membuat pilihan, berpikir positif, kemampuan untuk melakukan assertiveness kolektif, kemampuan mempelajari keterampilan untuk meningkatkan satu pribadi atau kelompok.

\section{METODE}

Metode penelitian yang digunakan dalam penelitian ini adalah metode deskriptif untuk mendapatkan informasi tentang pengambilan tindakan keputusan kepala sekolah dalam rangka pemberdayaan tenaga pendidik di Sekolah Polisi Negara Jambi. Pada penelitian ini, peneliti ingin meneliti bagaimana tindakan pengambilan keputusan kepala

sekolah Polisi Negara Jambi dalam rangka pemberdayaan tenaga pendidik, yang menjadi pusat perhatian dan sasaran peneliti dalam penelitian ini adalah: Kepala Sekolah Polisi Negara (SPN) Jambi, Sekretaris SPN Jambi, Kepala Bagian pengajaran dan pelatihan (Kabagjarlat) Sekolah Polisi Negara jambi, Koordinator tenaga pendidik dan Tenaga Pendidik sekolah Polisi Negara/SPN Jambi. Analisa penelitian ini menggunakan teknik statistik deskriptif.

\section{HASIL DAN PEMBAHASAN}

Pembahasan terhadap temuan hasil penelitian, variabel penelitian terdiri dari dua variabel yaitu pengambilan keputusan dan pemberdayaan tenaga pendidik. Data diperoleh dari hasil pengisian kuesioner dengan jawaban yang bersifat ordinal, yaitu penilaian dengan menggunakan jenjang sebanyak 5 opsi jawaban. Data yang diperoleh dari kuesioner diolah dan disajikan dalam bentuk hasil analisis statistik deskriptif. Pernyataan di dalam variabel pengambilan keputusan berkaitan dengan penilaian karyawan yang diperoleh melalui angket dengan skor tertentu tentang tindakan pengambilan keputusan dengan beberapa indikatornya, yaitu: (1) identifikasi masalah ; (2) membuat alternatif solusi; (3) memilih solusi; (4) implementasi keputusan; dan (5) evaluasi implementasi.

Adapun, pernyataan pemberdayaan tenaga pendidik berkaitan dengan penilaian melalui angket dengan skor tertentu yang diperoleh dari responden mengenai program peningkatan kemampuan tenaga pendidik melalui pelatihan menyusun silabus, menyusun bahan ajar, menyusun desain pembelajaran, mengelola kelas dan menyusun penilaian hasil belajar indikatornya yaitu meningkatnya motivasi, kompetensi, percaya diri, kemandirian dan meningkatkan kerjasama. 
Dari indikator indentifikasi masalah diketahui bahwa Kepala Sekolah Polisi Negara Jambi telah mengidentifikasi aspek-aspek penting untuk mengatasi kelemahan yang menjadi kendala tenaga pendidik dalam melaksanakan tugas pokok yaitu: membuat silabus, menyusun bahan pengajaran, membuat desain pembelajaran, mengelola kelas dan menyusun penilaian hasil belajar.

Indikator keberhasilan membuat alternatif solusi pada pengambilan keputusan kepala sekolah dalam rangka pemberdayaan tenaga pendidik, untuk mengatasi kelemahan yang menjadi kendala tenaga pendidik dalam melaksanakan tugas pokok dilakukan oleh Kepala Sekolah Polisi Negara Jambi, membuat beberapa alternatif solusi yang telah dipertimbangkan sesuai dengan kebutuhan tenaga pendidik. Alternatif solusi yang dibuat oleh Kepala Sekolah Polisi Negara Jambi dimaksudkan untuk mengantisipasi apabila alternatif pertama tidak berhasil, maka ada alternaif lain yang menjadi pilihan.

Tindakan membuat solusi alternatif dengan mempertimbangkan peluangpeluang yang ada pada Sekolah Polisi Negara Jambi dan memperkirakan kemungkinan kendala-kendala yang akan terjadi, sangat membantu kepala sekolah dalam memilih dan menetapkan program. Pada tahap membuat alternatif solusi kepala sekolah sebagai pembuat keputusan dapat menggunakan waktunya semaksimal mungkin dalam membuat keputusan, mengevaluasi batasan-batasan, dan mengkaji solusi alternatif lainnya.

Pembuatan solusi alternatif yang dilakukan kepala sekolah mempertimbangkan aspek yang terkait erat dengan upaya-upaya meningkatnya kualitas hasil didik, dengan pilihan-pilihan dan pertimbangan-pertimbangan yang logis, ekonomis, rasional dan pertimbangan kualitas, seperti penggunaan sarana dan peralatan yang ada, fasilitas tempat yang sudah tersedia, dana yang tidak terlalu besar dan pendekatan pembelajaran aktif.

Pada indikator memilih alternatif solusi ini termasuk tinggi. Hal tersebut tercermin pada saat memilih program pelatihan peningkatan kemampuan tenaga pendidik, pilihan

yang menjadi prioritas dan merupakan kebutuhan untuk mengatasi kelemahan yang merupakan kendala tenaga pendidik dalam melaksanakan tugas pokok, yaitu pembuatan silabus, menyusun bahan pengajaran, membuat desain pembelajaran, mengelola kelas dan menyusun penilaian hasil belajar di Sekolah Polisi Negara Jambi merupakan pilihan yang tepat. Masalah lain yang perlu disikapi adalah terjadinya mutasi tugas tenaga pendidik yang berkualitas ke bidang tugas operasional kewilayahan sehingga tenaga pendidik baru perlu dilatih kemampuannya.

Indikator keberhasilan dalam implementasi keputusan yang dilakukan oleh Kepala sekolah Polisi Negara Jambi, menunjukkan klasifikasi yang tinggi, terutama dalam hal penyelenggaraan pelatihan. Hal itu tercermin dalam penyelenggaraan program pelatihan yang sesuai dengan perencanaan yang meliputi kebutuhankebutuhan serta menyediakan sarana dan prasarana program pelatihan sesuai dengan tujuan program pelatihan. Selain itu, kepala sekolah juga berhasil dalam menyediakan tenaga pengajar untuk program pelatihan berdasarkan jumlah peserta dan materi yang disampaikan. Dari hasil wawancara tentang penerapan keputusan oleh Kepala Sekolah Polisi Negara Jambi diperoleh keterangan bahwa: implementasi pengambilan keputusan untuk mengatasi kelemahan yang menjadi kendala tenaga pendidik dalam melaksanakan tugas pokok, dilakukan oleh kepala sekolah dalam rangka meningkatkan 
kemampuan tenaga pendidik meliputi aspek yang terkait erat dengan upaya-upaya meningkatnya kualitas hasil didik.

Responden menyatakan bahwa implementasi pengambilan keputusan adalah menerapkan program yang sudah menjadi pilihan. Program yang menjadi pilihan untuk meningkatkan kemampuan tenaga pendidik adalah melatih 20 orang tenaga pendidik, dengan alokasi waktu latihan 12 hari, penyelanggaraan tempat latihan adalah di Sekolah Polisi Negara Jambi. Implementasi dari pengambilan keputusan kepala sekolah tersebut dilakukan dengan : menyusun perencanaan latihan, melakukan analisa kebutuhan latihan, membuat perincian anggaran dengan cermat, menyusun materi latihan, menyusun jadwal latihan, menyiapkan peralatan latihan, menyiapkan sarana dan prasaran latihan, melakukan seleksi peserta dan kepala sekolah mengendalikan serta mengawasi pelaksanaan latihan.

Evaluasi implementasi meliputi penilaian terhadap perencanaan program pelatihan, proses dan hasil pelatihan. Evaluasi implementasi difokuskan kepada seluruh proses penyelenggaraan program, kemudian data yang diperoleh digunakan sebagai informasi untuk mengembangkan program pelatihan berikutnya. Dari jawaban kuesioner tergambar bahwa penyelenggaraan program pelatihan tenaga pendidik yang dilaksanakan di Sekolah Polisi Negara Jambi sudah direncanakan dengan baik. Hasil wawancara dapat memperkuat data diatas sebagai berikut:

Evaluasi Implementasi keputusan Kepala Sekolah Polisi Negara Jambi dilakukan untuk mengetahui apakah program yang sudah diputuskan berjalan sesuai perencanaan atau sebaliknya. 1) mengevaluasi perencanaan program, untuk mengetahui kelemahan dan keberhasilan suatu perencanaan. 2) mengevaluasi proses untuk mengetahui kendalakendala dan keberhasilan yang terjadi ketika proses latihan berlangsung. 3) mengevaluasi hasil program. Setelah evaluasi implementasi selanjutnya yang dilakukan oleh kepala sekolah adalah memberdayakan tenaga pendidik (1) melatihkan kembali ilmu yang telah didapat kepada tenaga pendidik yang lain, (2) menerapkan keterampilan yang didapat

pada pelaksanaan proses pembelajaran, (3) mengembangkan kurikulum. Pengambilan keputusan Kepala Sekolah Polisi Jambi dalam rangka pemberdayaan tenaga pendidik telah meningkatkan kualitas individu dalam suatu organisasi dan membentuk pekerja menjadi mandiri dan percaya diri serta memiliki kemampuan mengambil keputusan sesuai dengan wewenang dan kompetensi yang dimiliki.

Pada indikator meningkatkan motivasi, pelatihan kemampuan tenaga pendidik dalam hal menyusun silabus, bahan pengajaran, desain pembelajaran, mengelola kelas dan menyusun penyusun penilaian hasil belajar menggambarkan meningkatnya motivasi tenaga pendidik, pemberdayaan tenaga pendidik yang dilakukan di Sekolah Polisi Negara Jambi telah meningkatkan pengetahuan, pengalaman dan keterampilan berdampak pada meningkatnya motivasi.

Pada indikator meningkatkan kompetensi, pelatihan kemampuan tenaga pendidik dalam hal menyusun silabus, bahan pengajaran, desain pembelajaran, mengelola kelas dan menyusun penyusun penilaian hasil belajar menggambarkan meningkatnya kompetensi tenaga pendidik.

Pada indikator meningkatkan kemandirian, pelatihan kemampuan tenaga pendidik dalam hal menyusun silabus, bahan pengajaran, desain pembelajaran, mengelola kelas dan menyusun penyusun penilaian hasil belajar menggambarkan meningkatnya kemandirian tenaga pendidik. Peningkatan kemampuan tenaga pendidik yang diarahkan pada kemampuan individu dimaksud untuk meningkatkan 
kemandirian mulai dari pemahaman terhadap materi pelatihan sampai dengan pencapaian standar keterampilan yang harus dikuasai.

Pada indikator meningkatkan percaya diri, pelatihan kemampuan tenaga pendidik dalam hal menyusun silabus, bahan pengajaran, desain pembelajaran, mengelola kelas dan menyusun penyusun penilaian hasil belajar menggambarkan meningkatnya percaya diri tenaga pendidik. Peningkatan kemampuan tenaga pendidik yang dilakukan oleh Sekolah Polisi Negara Jambi berarti telah memberikan kepercayaan dan kekuatan kepada individu untuk menerapkan pengetahuan dan keterampilannya.

Pada indikator meningkatkan kerjasama menggambarkan bahwa kerjasama tenaga pendidik semakin meningkat setelah pelatihan peningkatan kemampuan tenaga pendidik dalam hal menyusun silabus, bahan pengajaran, desain pembelajaran, mengelola kelas dan menyusun penyusun penilaian hasil belajar.

Nilai rangkuman deskripsi data dari kedua variabel yang terdapat dalam tabel secara keseluruhan berada di atas rata-rata, terlihat dari hasil perhitungan skor yaitu variabel pengambilan pengambilan keputusan 93,60 dan variabel pemberdayaan 81,57 artinya bahwa tindakan pengambilan keputusan yang dilakukan Kepala Sekolah Polisi Negara Jambi dalam rangka pemberdayaan tenaga pendidik telah dapat pengatasi masalah yang merupakan kendala tenaga pendidik dalam melaksanakan tugas pokoknya. Nilai rata-rata skor variabel pengambilan keputusan kepala sekolah yaitu 93,60 atau $74,88 \%$ dari skor maksimum teoretik sebesar 150 . Sedangkan untuk variabel pemberdayaan tenaga pendidik nilai rata-rata 103,2 atau $68 \%$ dari skor maksimum. Artinya pengambilan keputusan Kepala Sekolah Polisi Negara Jambi dalam rangka pemberdayaan tenaga pendidik merupakan tindakan yang sangat rasional untuk mengatasi masalah dan kelemahan yang menjadi kendala tenaga pendidik dalam

melaksanakan tugas pokok. Pengambilan keputusan Kepala Sekolah Polisi Jambi dalam rangka pemberdayaan tenaga pendidik telah meningkatkan kualitas individu dalam suatu organisasi dan membentuk tenaga pendidik menjadi meningkat motivasi, kompetensi, mandiri dan percaya diri serta meningkatnya kerjasama memiliki kemampuan mengambil keputusan sesuai dengan wewenang dan kompetensi yang dimiliki.

\section{PENUTUP}

Kesimpulan. Berdasarkan hasil penelitian ini dapat disimpulkan bahwa: (1) Mengatasi permasalahan yang dihadapi di Sekolah Polisi Negara Jambi terutama masalah yang merupakan kelemahan dan menjadi kendala bagi tenaga pendidik dalam melaksanakan tugas pokok, maka kepala sekolah perlu membuat keputusan untuk menetapkan program dengan terlebih dahulu mengindentifikasi masalah, membuat alternatif solusi, memilih solusi yang tepat dan prioritas dan mengimplementasikan keputusan serta mengevaluasi keputusan sehingga masalah yang dihadapi dapat diselesaikan sesuai dengan harapan. (2) Kepala sekolah yang ingin meningkatkan motivasi, kompetensi, kemandirian, percaya diri dan kerjasama, agar dapat mengatasi kelemahan yang merupakan kendala tenaga pendidik dalam melaksanakan tugas pokoknya, maka kepala sekolah membuat program peningkatan pengetahuan dan keterampilan dalam bentuk pelatihan dengan materi yang telah dipilih dan ditetapkan sebelumnya yaitu: menyusun silabus, menyusun bahan pengajaran, membuat desain pembelajaran, mengelola kelas dan menyusun penilaian hasil belajar. (3) Tindakan pengambilan keputusan yang dilakukan Kepala Sekolah Polisi Negara Jambi telah meningkatkan 
kualitas individu, tenaga pendidik, meningkatkan kompetensi, motivasi, dan kerjasama dalam organisasi sekolah dan memberdayakan tenaga pendidik menjadi lebih mandiri dan percaya diri serta memiliki kemampuan mengambil keputusan sesuai dengan wewenang dan kompetensi yang dimiliki. Dengan demikian pengambilan keputusan kepala Sekolah Polisi Negara Jambi dalam rangka pemberdayaan tenaga pendidik telah dapat mengatasi masalah yang terjadi di sekolah Polisi Negara Jambi.

Saran. Berdasarkan temuan penelitian dan pembahasan yang telah disimpulkan maka peneliti menyampaikan saran sebagai berikut : Pertama, kepada Kepala Sekolah Polisi Negara Jambi, pengambilan keputusan kepala sekolah dalam rangka pemberdayaan tenaga pendidik merupakan salah satu cara dari sekian banyak upaya untuk meningkatkan kualitas hasil didik. Langkah-langkah pengambilan keputusan yang dilakukan hendaknya melalui tahap identifikasi masalah, membuat beberapa alternatif solusi, memilih solusi yang tepat serta melakukan evaluasi, agar keputusan yang diambil dapat membantu mewujudkan program peningkatan mutu hasil didik di Sekolah Polisi Negara Jambi sesuai harapan pimpinan dan tuntutan masyarakat. Kedua, Kepada Kepala Lembaga Pendidikan dan Pelatihan Polri, hendaknyan dapat menjadikan hasil penelitian ini sebagai bahan masukan dan pertimbangan untuk menentukan kebijaksanaan lebih lanjut

\section{DAFTAR RUJUKAN}

Alan Randolph dan Ken Blancahard. leading at a higher level. Jakarta: Elex Media Komputindo, 2002.

Gibson, James L dan John M. Ivancevich. Organizations behavior structure processes. New York: McGraw-Hill, 2006.

Gore and Dyson. The making of decision: a reader in administration behavior, 1964.

Kreitner, Robert \& Angelo Kinicki. Organizational Behavior: Key concepts, Skill \& Best Practice. New York: McGraw-Hill, 2008.

Northcraft, Gregory B \& Margareta A. Neale. Organizational Behavior. New York: lizwiddicombe, 1994. 
